\title{
CLAY-MINERAL TRANSFORMATIONS AND HEAVY-METAL RELEASE IN PADDY SOILS FORMED ON SERPENTINITES IN EASTERN TAIWAN
}

\author{
Zeng-Yei Hseu $^{1, *}$, Franz Zehetner $^{2}$, Franz Ottner $^{3}$, and Yoshi Iizuka ${ }^{4}$ \\ ${ }^{1}$ Department of Agricultural Chemistry, National Taiwan University, Taipei 10617, Taiwan \\ 2 Institute of Soil Research, University of Natural Resources and Life Sciences, A-1190 Vienna, Austria \\ ${ }^{3}$ Institute of Applied Geology, University of Natural Resources and Life Sciences, A-1190 Vienna, Austria \\ ${ }^{4}$ Institute of Earth Sciences, Academia Sinica, Taipei 11529, Taiwan
}

\begin{abstract}
Serpentinites, which contain high concentrations of $\mathrm{Cr}$ and $\mathrm{Ni}$, weather easily into layer silicates and are therefore a possible source of metal contamination in soils. In the present study three soil profiles formed on serpentinites in a paddy field in eastern Taiwan were investigated to understand pedogenic clay-mineral transformations and to determine the relationship between the mineralogical characteristics and labile $\mathrm{Cr}$ and $\mathrm{Ni}$ in the soil. To this end, physicochemical analyses, micromorphology, $\mathrm{X}$-ray diffraction, and Fourier transform infrared spectroscopy were employed. Serpentine and chlorite were the dominant minerals in the soil parent material, with smaller amounts of pyroxene, amphibole, and talc. Progressive weathering and the release of cations from the parent material resulted in the pedogenic formation of smectite, vermiculite, and interstratified chlorite-vermiculite, demonstrated by their presence in all $\mathrm{Ap}$ and $\mathrm{AC}$ horizons but their absence from the $\mathrm{C}$ horizons. Serpentine, pyroxene, amphibole, and talc are proposed to be transformed to low-charge smectite, while chlorite transformed to vermiculite through an interstratified chlorite-vermiculite phase. The surface soils were enriched in oxalate-extractable Fe relative to the subsoils, which was probably generated by the artificial flooding and draining of the paddy soils. The artificial flooding, which typically releases Fe, may also drive the observed partial hydroxyl interlayering of smectite and incomplete interlayer $\mathrm{OH}$ sheets of chlorite. Labile $\mathrm{Cr}$ and $\mathrm{Ni}$ (extracted with $0.1 \mathrm{~N} \mathrm{HCl}$ ) ranging from 4.7 to $26.8 \mathrm{mg} \mathrm{kg}^{-1}$ and from 56 to $365 \mathrm{mg} \mathrm{kg}^{-1}$, respectively, increased significantly toward the surface soil, consistent with weathering. The heavy metals released may pose a threat to the environment as well as to human health by entering the food chain.
\end{abstract}

Key Words-Chlorite, Heavy Metal, Paddy Soil, Serpentine, Smectite, Vermiculite.

\section{INTRODUCTION}

Serpentinites are formed by hydrothermal metamorphism of ultramafic rocks such as peridotites and pyroxenites. During the metamorphism, the anhydrous ultramafic rocks become more hydrous and $\mathrm{Ca}$ content decreases, resulting in an enrichment of $\mathrm{Mg}$ in the serpentinites (O'Hanley, 1996). Serpentine is the name of a class of minerals of which antigorite, lizardite, and chrysotile are the most recognized members (Wicks and O'Hanley, 1988). Serpentinites also contain minor amounts of chromite, magnetite, brucite, and talc (McGahan et al., 2008, 2009; Morrison et al., 2009). Apart from spinel-group minerals with high resistance to weathering (e.g. chromite and magnetite) (Hseu and Iizuka, 2013), most minerals of serpentinites are relatively unstable at near-surface conditions and weather easily into other layer silicates (Rabenhorst et al., 1982; Dixon, 1989; Alexander, 2014). The chemical weathering of serpentinites has been studied widely for their large Cr- and Ni-ore deposits (Gaudin et al., 2005;

* E-mail address of corresponding author:

zyhseu@ntu.edu.tw

DOI: 10.1346/CCMN.2015.0630204
Wanze et al., 2008; Yongue-Fouateu et al., 2009), but serpentinitic soils have attracted the interest of soil scientists for additional reasons. Serpentinitic soils have severe fertility limitations because of low $\mathrm{Ca} / \mathrm{Mg}$ ratios (McGahan et al., 2008, 2009), low concentrations of $\mathrm{P}$ and K (Brooks, 1987; Bonifacio and Barberis, 1999), and enrichments in $\mathrm{Cr}$ and $\mathrm{Ni}$ (Hseu, 2006; Cheng et al., 2009; Becquer et al., 2010; Cheng et al., 2011). They further show a unique flora (Whittaker, 1954; Oze et al., 2008) and have unique physical properties (Alexander et al., 2007).

Although serpentinites cover only a small fraction of Earth's terrestrial surface area, they are abundant in ophiolite belts and widespread in regions of the CircumPacific margin and Mediterranean Sea (Oze et al., 2007). Soil-mineralogical studies have contributed significantly to the understanding of serpentinite weathering and associated environmental consequences. For instance, the release of $\mathrm{Cr}$ and $\mathrm{Ni}$ into ecosystems during serpentinite weathering suggests that serpentinite landscapes are a possible source of non-anthropogenic metal contamination (Fantoni et al., 2002; Oze et al., 2007; Morrison et al., 2009; Economou-Eliopoulos et al., 2011). Serpentine, talc, chlorite, vermiculite, smectite, and interstratified minerals have been considered as the dominant phyllosilicate minerals in serpentinitic soils under various climates (Rabenhorst et al., 1982; Caillaud 
et al., 2006; Hseu et al., 2007; Lessovaia and Polekhovsky, 2009; Garnier et al., 2009). The genesis of weathering products in serpentinitic soils along a moisture-regime gradient was explored by Lee et al. (2003) who suggested that chlorite transformed to vermiculite and interstratified chlorite-vermiculite with progressive release of $\mathrm{Mg}$ from the brucitic layer of the chlorite. Smectite may be inherited from parent materials (Rabenhorst et al., 1982), but also formed from other clay minerals in serpentinitic soils (Bonifacio et al., 1997; Hseu et al., 2007). The formation of smectite may be associated with limited cation leaching, and $\mathrm{Mg}$ enriched weathering products of serpentinites may accumulate and contribute to the synthesis of smectite in poorly drained soils. In a serpentinitic soil catena of southwestern Oregon, USA, Istok and Harward (1982) found serpentine and chlorite in well drained upland soils, but serpentine, chlorite, and smectite in poorly drained soils. Bonifacio et al. (1997) demonstrated that serpentine could weather to low-charge vermiculite in well drained landscape positions and to smectite in poorly drained sites.

Paddy rice is an important cereal crop in global agriculture and second only to wheat in terms of the planting area of cereal crops (Kyuma, 2004). Global rice production is mainly distributed throughout Monsoon Asia with $>90 \%$ of the world's rice-growing area occurring in this region (Kyuma, 2004). Serpentinitic landscapes are found commonly in Monsoon Asia, adjacent to the convergent boundary of the Eurasian Plate and the Pacific Plate. Serpentinites are generally unstable in soils (Bonifacio et al., 1997) and may release considerable amounts of heavy metals, notably $\mathrm{Cr}$ and $\mathrm{Ni}$, to the environment upon weathering (Cheng et al., 2011). To date, only limited information is available on serpentinite weathering and associated release of heavy metals in paddy fields. An unresolved question is whether the lability of $\mathrm{Cr}$ and $\mathrm{Ni}$ in serpentinitic paddy soils is related to mineral transformations. To answer this question, we investigated paddy soil profiles formed on serpentinites in eastern Taiwan. The aims of this study were: (1) to identify the minerals and their alteration in the studied profiles, (2) to explore the transformation of clay minerals in the course of serpentinite weathering, and (3) to link the mineral weathering to the release of $\mathrm{Cr}$ and $\mathrm{Ni}$ in the soil.

\section{MATERIALS AND METHODS}

\section{Area description and sample collection}

The study area $\left(23^{\circ} 42^{\prime} 78^{\prime \prime} \mathrm{N}, 121^{\circ} 24^{\prime} 46^{\prime \prime} \mathrm{E}\right)$ is on an alluvial plain located at the northern part of the Huadong longitudinal valley (HLV) in eastern Taiwan at an altitude of $\sim 150 \mathrm{~m}$ above sea level. The HLV is a long, narrow rift stretching for $\sim 180 \mathrm{~km}$ and ranging from 2 to $7 \mathrm{~km}$ in width, flanked by the Central Ridge to the west and the Coastal Range to the east.
The soils' parent materials in the study area contain serpentinitic alluvium of Holocene age, which originates from blocks of serpentinite that crop out in the eastern section of the Central Ridge. Three replicate pedons were selected from a paddy field, and profile pits were excavated to the depth of the $\mathrm{C}$ horizon. The total area of paddy fields on the alluvial plain studied is $\sim 85,000 \mathrm{~m}^{2}$. The distance of the paddy field studied from the upslope serpentinite sources is $\sim 1.2 \mathrm{~km}$. Paddy rice, which is generally cropped twice a year, has been produced for $\sim 50 \mathrm{y}$ in the study area. Seasonal saturation and reduction are common features in paddy rice fields in Taiwan (Hseu and Chen, 2001). During the rice-growing season, the surface soils are anoxic while the subsoils are in a more oxic state (Hseu and Chen, 1996). For a paddy soil in the HLV area, Chen (2013) reported redox potentials (Eh) from -100 to $-300 \mathrm{mV}$ during the ricegrowing season (February-June, 2013) which increased to values between 100 and $350 \mathrm{mV}$ after the soil was drained in the fallow season (July-September, 2013).

The area is characterized by high temperature and humidity. Mean annual rainfall in the study area is $1800 \mathrm{~mm}$, and the mean annual air temperature is $22.5^{\circ} \mathrm{C}$ (mean monthly temperatures range from 18 to $27^{\circ} \mathrm{C}$ ). The soil moisture regime is udic, and the soil temperature regime is hyperthermic according to US Soil Taxonomy (Soil Survey Staff, 1993).

\section{Physical and chemical analyses}

The soil samples obtained from each horizon were air-dried, ground, and passed through a $2-\mathrm{mm}$ sieve for subsequent laboratory analyses. Soil particle-size distribution was determined by the pipette method (Gee and Bauder, 1986). Soil pH was measured in a mixture of soil and deionized water $(1: 1, \mathrm{w} / \mathrm{v})$ using a glass electrode (McLean, 1982). Total organic carbon (OC) content was determined using the Walkley-Black wet oxidation method (Nelson and Sommers, 1982). Cation exchange capacity (CEC) and exchangeable bases (K, $\mathrm{Na}, \mathrm{Ca}$, and $\mathrm{Mg}$ ) were determined by the ammonium acetate method (pH 7.0) (Rhoades, 1982). Total free and short-range ordered (non-crystalline) Fe (oxyhydr)oxides $\left(\mathrm{Fe}_{\mathrm{d}}\right.$ and $\mathrm{Fe}_{\mathrm{o}}$, respectively) were extracted with dithionite-citrate-bicarbonate (DCB) (Mehra and Jackson, 1960) and 0.2 M ammonium oxalate (pH 3.0) (McKeague and Day, 1966), respectively. Labile $\mathrm{Cr}$ and $\mathrm{Ni}$ were extracted by horizontal shaking $(10-\mathrm{cm}$ amplitude, $160 \mathrm{rpm}$ ) of $10 \mathrm{~g}$ of soil with $100 \mathrm{~mL}$ of $0.1 \mathrm{~N} \mathrm{HCl}$ in polypropylene tubes for $1 \mathrm{~h}$ (Baker and Amacher, 1982). All extracts were filtered using Whatman No. 42 filter paper and a nitrocellulose membrane filter $<0.45 \mu \mathrm{m}$ (Millipore, Billerica, Mississippi, USA). Metal contents in all of the above solutions were determined using a flame atomic absorption spectrometer (Hitachi Z-2300, Tokyo, Japan). In addition, analysis of major and trace elements in the soil samples was conducted using wavelength-dispersive 
X-ray fluorescence (XRF). Major ( $\mathrm{Si}, \mathrm{Al}, \mathrm{Fe}, \mathrm{Mg}, \mathrm{Ca}, \mathrm{K}$, $\mathrm{Na}$, and $\mathrm{Ti}$ ) and trace elements $(\mathrm{Mn}, \mathrm{Cr}$, and $\mathrm{Ni}$ ) were measured using an XRF spectrometer (Spectro Xepos, Mahwah, New Jersey, USA), following the method of Norrish and Hutton (1969). Significant differences in basic soil characteristics and elemental contents were analyzed with Duncan's multiple range test $(p<0.05)$.

\section{Micromorphological studies of rock and soil}

For micromorphological studies, Kubiena boxes were used to collect undisturbed rock and soil blocks in the field. After air drying, vertically oriented thin sections with a thickness of $30 \mu \mathrm{m}$ were prepared and polished by Spectrum Petrographics, Inc., Vancouver, Washington, USA. Thin sections were examined for all horizons with polarized light microscopy (Leica DM 2700 P, Wetzlar, Germany). Selected areas of uncovered thin sections were carbon-coated and further examined with a scanning electron microscope (SEM) (JEOL JSM-6360LV, Tokyo, Japan) at the Institute of Earth Sciences, Academia Sinica, Taipei, Taiwan. Back-scattered electron (BSE) images and elemental spectra by energy dispersive X-ray spectroscopy (EDX) were acquired at an accelerating voltage of $20 \mathrm{kV}$, a beam current of $20 \mathrm{~mA}$, a spot size of $\sim 1 \mu \mathrm{m}$, and counting times of $30 \mathrm{~s}$ for $\mathrm{Si}, \mathrm{Fe}, \mathrm{Al}$, and $\mathrm{Mg}$ and of $20 \mathrm{~s}$ for the other elements. Minerals and synthetic oxides were used as standards. In addition to the approaches for undisturbed soil blocks, the surface morphology of asbestos was also examined by SEM. Fibrous materials were obtained from the surface of a fresh serpentinitic rock, freeze-dried, ground, and suspended in water. A drop of the suspension was then evaporated on a carboncoated copper grid (300 mesh, $3.05 \mathrm{~mm}$ in diameter) and the prepared sample was examined by a field emission SEM (Hitachi-4700, Tokyo, Japan) in secondary electron imaging mode.

\section{$X$-ray diffraction and infrared spectroscopy of rock and soil}

$\mathrm{X}$-ray powder diffraction (XRD) was conducted on the parent-rock material from the bottom of the soil profiles, and on clay-size fractions. The random powder XRD technique was used to determine the mineralogy of the rock. For the analysis of clay minerals with XRD and Fourier transform infrared (FTIR) spectroscopy, airdried soil samples were pretreated with $30 \% \mathrm{H}_{2} \mathrm{O}_{2}$ to remove organic matter, and then treated with the $\mathrm{DCB}$ method to remove iron-oxide coatings. The clay $(<2 \mu \mathrm{m})$ fraction was separated using continuous-flow centrifugation, and cation-saturated samples were prepared using $1 \mathrm{M} \mathrm{KCl}$ and $1 \mathrm{M}\left(\mathrm{CH}_{3} \mathrm{COO}\right)_{2} \mathrm{Mg}$. K-saturated samples were examined at room temperature and after heating to $350^{\circ} \mathrm{C}$ and $550^{\circ} \mathrm{C}$, and $\mathrm{Mg}$-saturated samples were examined at room temperature and after glycerol treatment. X-ray diffraction of oriented clay specimens was performed in a Rigaku D/max-2200/PC (Tokyo, Japan) with $\mathrm{Ni}$-filtered $\mathrm{CuK} \alpha$ radiation generated at
$30 \mathrm{kV}$ and $10 \mathrm{~mA}$; samples were scanned from 2 to $50^{\circ} 2 \theta$, at a rate of $0.2^{\circ} 2 \theta \mathrm{min}^{-1}$. Using the reciprocal mineral intensity factors summarized by Kahle et al. (2002), semi-quantitative determination of the clay minerals was based on the difference of reflection patterns from the $\mathrm{K}$-saturated, Mg-saturated, glycolated, heated, and air-dried samples (Johns et al., 1954). Additionally, selected thin sections were analyzed by means of X-ray micro diffraction using an X'Pert PRO MPD diffractometer with automatic divergence slit, $\mathrm{Cu}$ LFF tube (45 kV, $40 \mathrm{~mA}$ ) and a position-sensitive $\mathrm{X}$ 'Celerator detector (PANalytical, Almelo, the Netherlands). The X-ray beam was focused on the thin sections using a mono-capillary with a diameter of $0.5 \mathrm{~mm}$. The samples were scanned at a step size of $0.017^{\circ} 2 \theta$, with a measuring time of $100 \mathrm{~s}$ per step.

The parent-rock material and the soil clay fractions were also analyzed by FTIR spectroscopy. Samples were dried at $60^{\circ} \mathrm{C}$, ground in a steel grinder and passed through a 100-mesh sieve to form an homogeneous powder, of which $100 \mathrm{mg}$ was ground in a Specamill (Specac GS06002, Swedesboro, New Jersey, USA) to a particle size of $<1 \mu \mathrm{m}$. Powdered, dry samples $(\sim 10 \mathrm{mg})$ were ground with $1 \mathrm{~g}$ of dried $\mathrm{KBr}$ until homogeneous and pressed into pellets. Infrared (IR) absorption spectra were obtained using a Bruker Vector 22 FTIR spectrometer (Fremont, California, USA) in transmission mode from 400 to $4000 \mathrm{~cm}^{-1}$, with a resolution of $4 \mathrm{~cm}^{-1}$ using 16 scans.

\section{RESULTS}

\section{Parent materials}

Serpentine was the major groundmass in the parentrock material, with opaque inclusions of chromite staining the groundmass in the polarized light microscope (Figure 1a). Three polymorphs of serpentine, i.e. chrysotile, antigorite, and lizardite, were identified by their different textures. Veins of cross-fiber chrysotile co-exist with antigorite/lizardite in the weathered parent material (Figure 1b). In the subsoil, fragments of weathered ultramafic rocks as well as mineral particles originating from serpentinized ultramafics, e.g. serpentinized pyroxene (Figure 1c), were found. A small amount of strong-yellow pseudomorphs of clay and irregularly distributed brown Fe oxides on the surface of serpentine and soil structure were interpreted as transformed phases (Figure 1d).

Amphibole asbestos with needle-like shape and fibertype chrysotile asbestos were observed using SEM (Figure 2a,b, respectively). In addition to serpentine, chlorite and chromite were found in the samples (Figure $2 \mathrm{c}, \mathrm{d}$, respectively). Analysis by EDX indicated that $\mathrm{Cr}$ was the predominant element in the chromite with smaller amounts of Fe, Mg, Al, and Si (Figure 2e).

Powder XRD revealed a dominance of serpentine in the parent-rock material, with prominent peaks at 0.72 

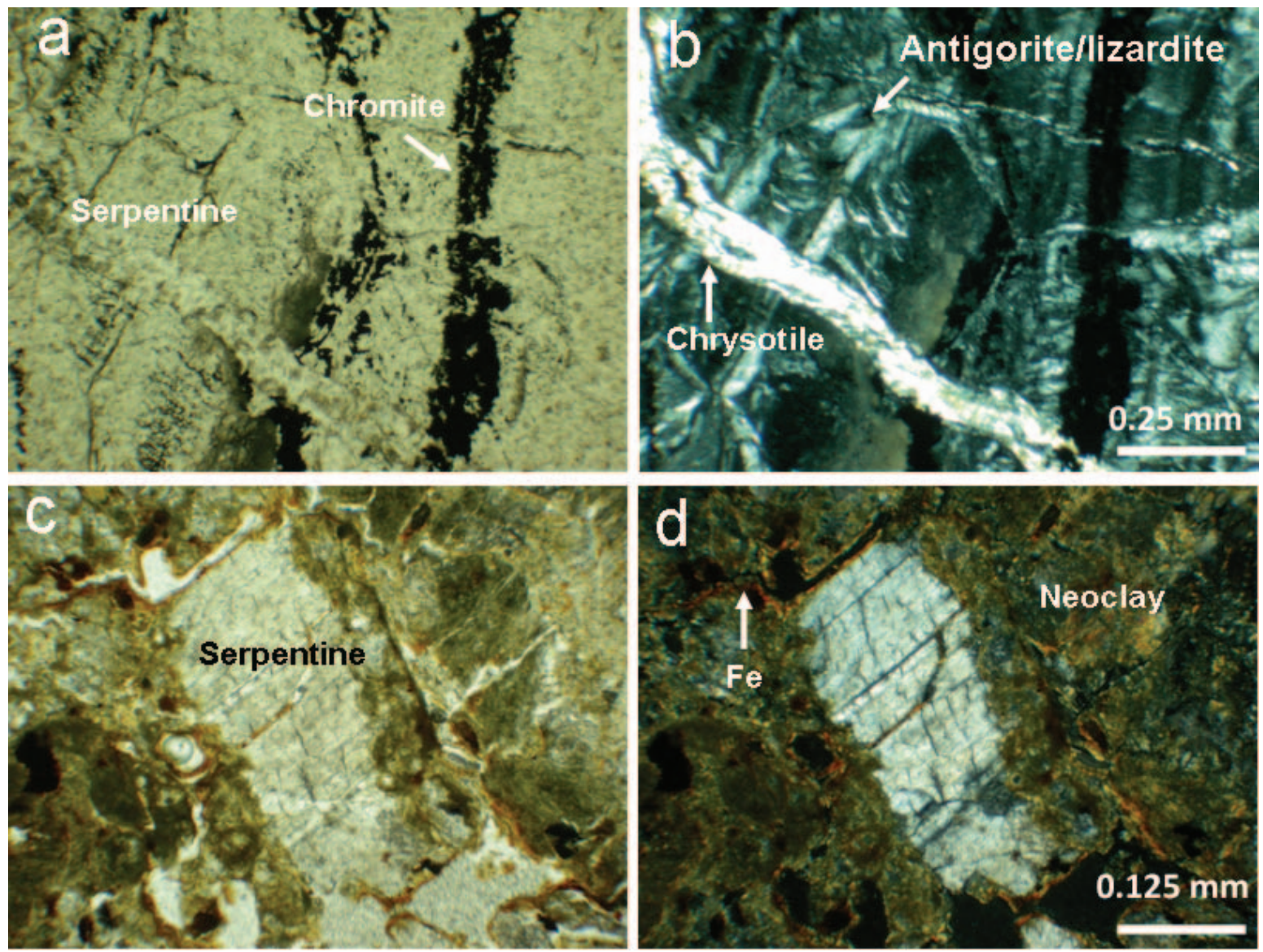

Figure 1. Photomicrographs: (a) serpentine matrix associated with opaque chromite in the parent-rock material of Pedon 1 under plane polarized light (PPL); (b) same image as (a) but under cross polarized light (XPL); (c) weathered serpentine surrounded by clay and pedogenic Fe oxides in the C horizon of Pedon 2 under PPL; (d) same image as (c) but under XPL.

and $0.36 \mathrm{~nm}$ (Figure 3 ). The XRD peaks at $1.41,0.72$, 0.48 , and $0.36 \mathrm{~nm}$ are indicative of chlorite. In addition to serpentine and chlorite, talc $(0.95,0.46$, and $0.31 \mathrm{~nm})$, amphibole $(0.85 \mathrm{~nm})$, chromite $(0.28$ and $0.20 \mathrm{~nm})$, mica $(1.00$ and $0.50 \mathrm{~nm})$, quartz $(0.43$ and $0.34 \mathrm{~nm})$, and plagioclase $(0.32 \mathrm{~nm})$ were also found by XRD (Figure 3). X-ray microdiffraction on a thin section from the AC horizon of Pedon 2 identified pyroxene, amphibole, chlorite, serpentine, plagioclase, muscovite, and quartz, at different spots (diameter $\approx 1 \mathrm{~mm}$ ), and notably revealed areas dominated by serpentine coexisting with areas where serpentine was not detectable (Figure 4).

\section{General soil properties}

The soil textures showed small clay contents in all pedons (Table 1). The $\mathrm{pH}$, which was $>7.0$ in all pedons, increased with soil depth. The OC content ranged between 0.9 and $1.8 \%$ and the CEC was between 5.1 and $8.6 \mathrm{cmol} \mathrm{kg}^{-1}$. The base saturation exceeded $60 \%$. The $\mathrm{Fe}_{\mathrm{o}} / \mathrm{Fe}_{\mathrm{d}}$ ratio was significantly $(p<0.05)$ higher in the Ap horizons than in the subsoils, indicating a greater abundance of short-range-ordered $\mathrm{Fe}$ oxides near the surface. The concentrations of $\mathrm{Cr}$ and $\mathrm{Ni}$ extracted with $0.1 \mathrm{~N} \mathrm{HCl}$ were clearly above the geochemical background levels in non-serpentine agricultural soils of Taiwan $\left(\sim 10 \mathrm{mg} \mathrm{kg}^{-1}\right.$, using $0.1 \mathrm{~N} \mathrm{HCl}$ extraction; Jien et al., 2011), and increased significantly $(p<0.05)$ toward the surface in the pedons studied. The $\mathrm{Ni}$ concentrations were much higher than those of $\mathrm{Cr}$ (Table 1).

The bulk elemental compositions of the soils exhibited relatively small $\mathrm{Si}$ contents ranging from 208 to $264 \mathrm{~g} \mathrm{~kg}^{-1}$, consistent with the Si-poor nature of ultramafic parent rocks (Table 2). Similarly, low Al contents corresponded with the geochemical characteristics of serpentinites shown in the literature (Caillaud et al., 2006; Hseu et al., 2007; Cheng et al., 2009). The indicator element in serpentinitic soils, $\mathrm{Mg}$, was present in much larger amounts than $\mathrm{Ca}$, reflecting its enrichment during metamorphism (O'Hanley, 1996). The pedons contained substantial amounts of $\mathrm{Cr}$ and $\mathrm{Ni}$, which were greater than those found in soils from other parent materials (Bonifacio et al., 1997; Oze et al., 2008). 

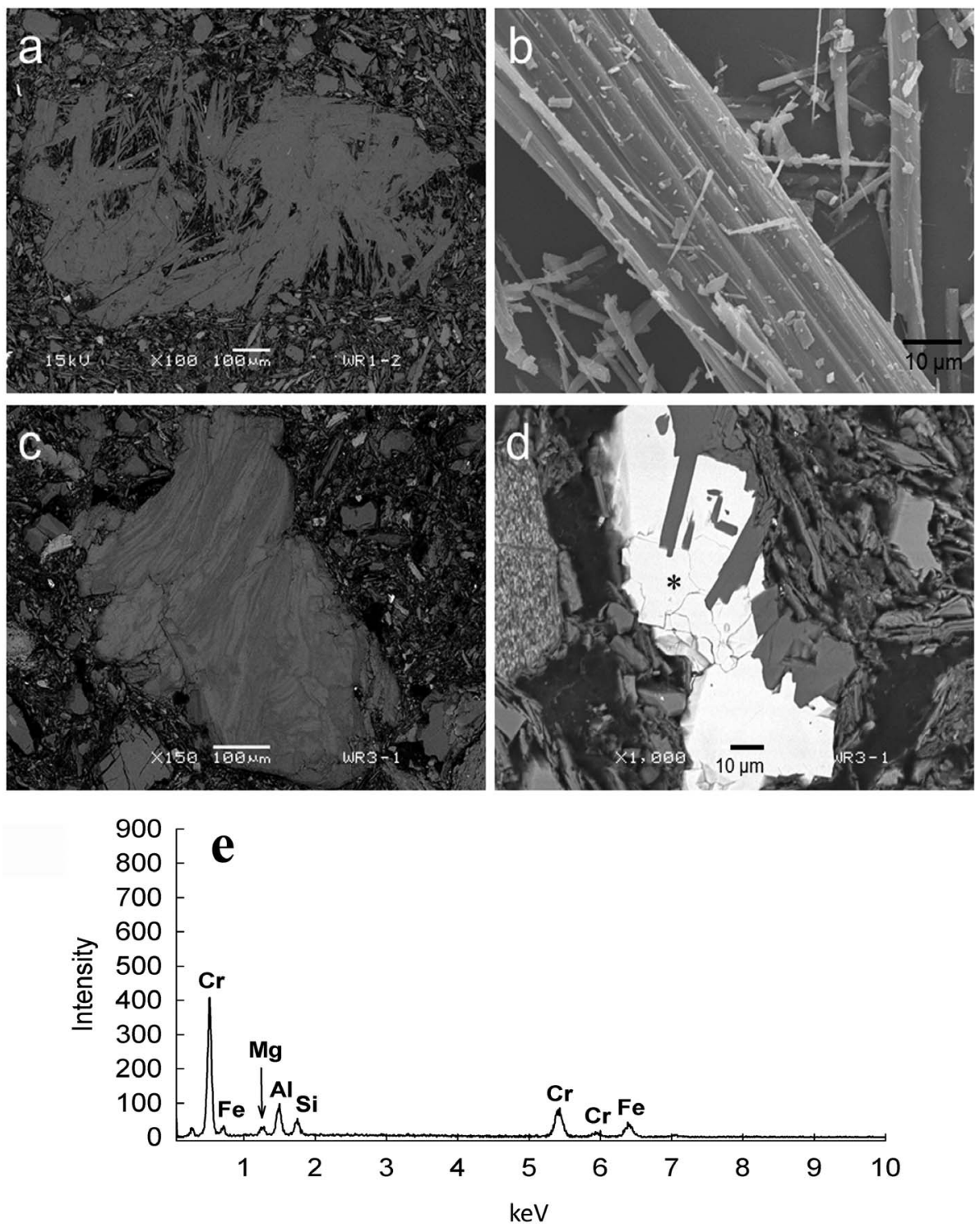

Figure 2. Back-scattered electron images of: (a) amphibole asbestos, (c) chlorite, (d) chromite, and (e) EDX spectroscopy of the spot marked with an asterisk in (d); (b) SEM secondary-electron image of chrysotile. All images from the C horizon of Pedon 3.

\section{Clay-mineral composition}

The minerals chlorite, smectite, mixed-layer chlorite-vermiculite, vermiculite, serpentine, mica, plagioclase, and chromite were identified at variable abundances in the clay fraction of the pedons studied (Table 3). The XRD patterns of the clay fraction from the Ap horizon of Pedon 3 are presented here as an example showing the clay mineralogy of the soils studied (Figure 5). Chlorite was clearly identified by the peaks at $1.41,0.72,0.48$, and $0.36 \mathrm{~nm}$, with the $0.72-\mathrm{nm}$ peak being reduced when heated to $550^{\circ} \mathrm{C}$. Chlorite was present in all soils, but the amount increased with soil depth (Table 3). Smectite was identified by its 1.4 to 1.5-nm spacing after $\mathrm{Mg}$ saturation which expanded to $\sim 1.82 \mathrm{~nm}$ after glycerol solvation and did not collapse completely to $1.0 \mathrm{~nm}$ after $\mathrm{K}$ saturation and heating to $550^{\circ} \mathrm{C}$ for $2 \mathrm{~h}$, suggesting partial hydroxyl interlayering of the smectite. This behavior was also observed in other studies of serpentinite-derived soils (Graham et al., 1990; Hseu et al., 2007). According to the reference $d_{001}$ values for different treatments reported by Lee $e t$ al. (2003), the smectite in the studied soils was a lowcharge type on the basis of the peaks at $1.82 \mathrm{~nm}$ with $\mathrm{Mg}$ saturation and glycerol solvation, $1.24 \mathrm{~nm}$ with $\mathrm{K}$ saturation at room temperature, and $1.0 \mathrm{~nm}$ with $\mathrm{K}$ saturation and heating to $550^{\circ} \mathrm{C}$ (Figure 5). Vermiculite was identified by the peak at $1.41 \mathrm{~nm}$ at room temperature, collapsing to $1.0 \mathrm{~nm}$ when the K-saturated clays were heated at $350^{\circ} \mathrm{C}$. The XRD peaks at $1.41 \mathrm{~nm}$ in the $\mathrm{Mg}$-saturated state and between 1.2 and $1.3 \mathrm{~nm}$ in 


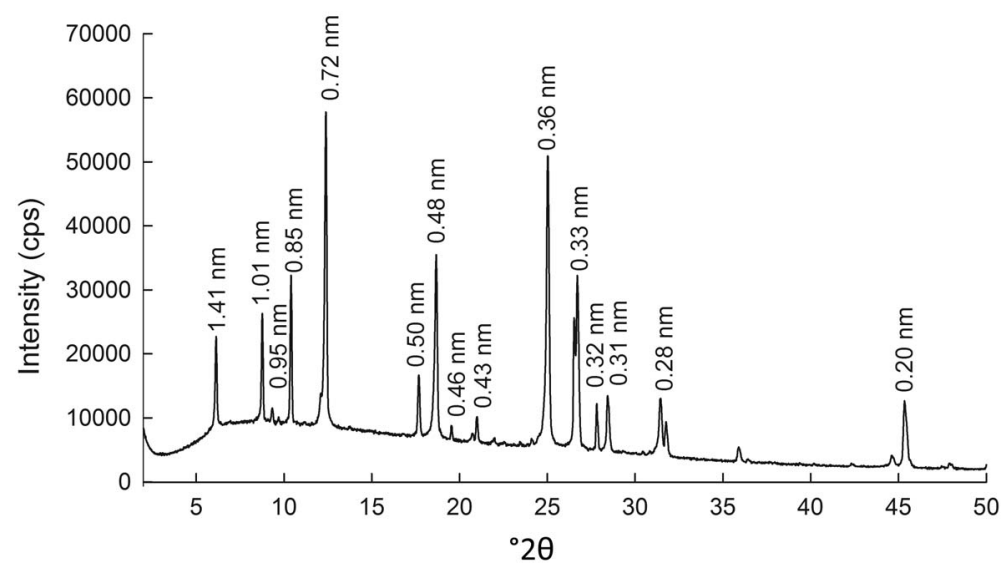

Figure 3. XRD pattern of the parent-rock material from the bottom of Pedon 1.

the $\mathrm{K}$-saturated state heated at $550^{\circ} \mathrm{C}$ are characteristic of randomly interstratified chlorite-vermiculite (Lee $e t$ al., 2003).
The FTIR spectrum of the parent-rock material exhibited characteristic IR bands in the region $3660-3770 \mathrm{~cm}^{-1}$ (Figure 6), which may, in part,
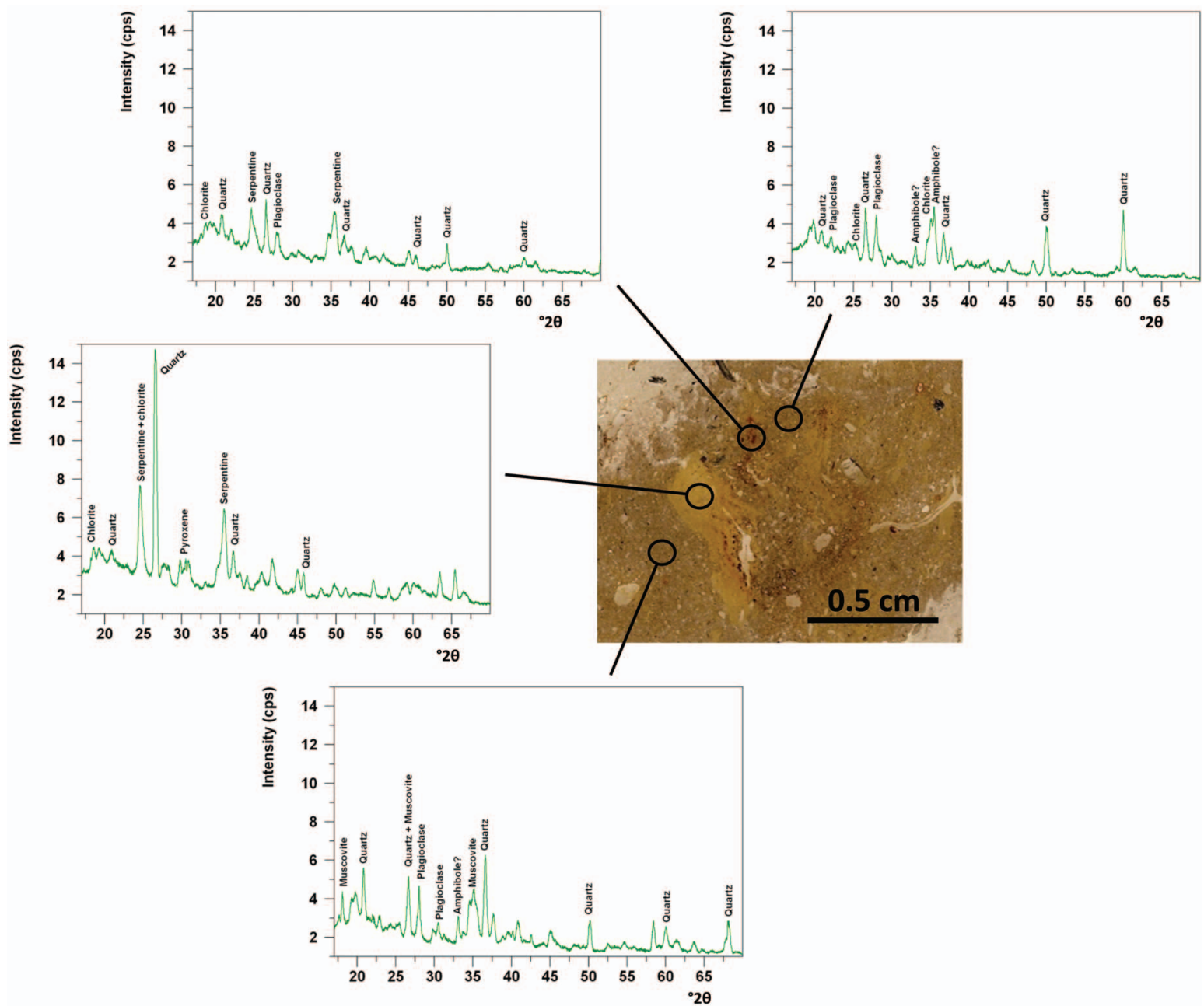

Figure 4. X-ray microdiffraction patterns of various spots (open circles, diameter $\approx 1 \mathrm{~mm}$ ) in a thin section of the AC horizon of Pedon 2 . 


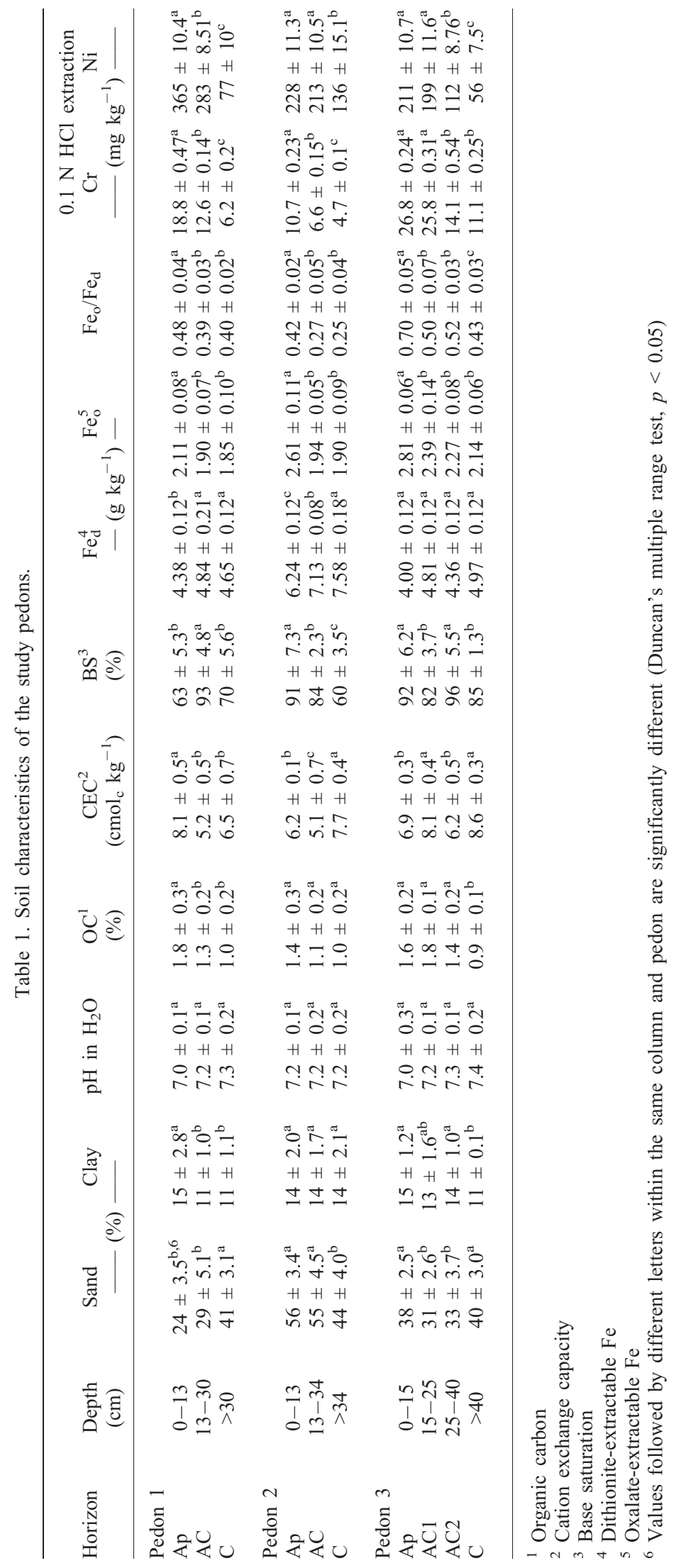


correspond to the $\mathrm{OH}$-stretching vibration of talc (Bangira et al., 2011). Moreover, the trioctahedral minerals chlorite, talc, and serpentine, identified in the rock powder on the basis of XRD (Figure 3), show a band near $3680 \mathrm{~cm}^{-1}$, which has been assigned to stretching vibrations of $\mathrm{Mg}_{3} \mathrm{OH}$ (Farmer, 1974; Lessovaia et al., 2012). Furthermore, the band at $670 \mathrm{~cm}^{-1}$ has been ascribed to $\mathrm{O}-\mathrm{H}$ libration and supports the presence of talc in the parent-rock material (Nkoumbou et al., 2008). The band at $467 \mathrm{~cm}^{-1}$ has been ascribed to an out-of-plane bending mode of $\mathrm{Mg}$ octahedra and assigned to serpentine (Suquet, 1989). All of the above-mentioned bands, however, were much more distinct in the parent-rock material compared to the clay fractions of the soils (cf. Figure 6). The distinct IR band at $819 \mathrm{~cm}^{-1}$, which was found in the clay fractions of the soils but not in the parent-rock material (Figure 6), is a characteristic feature of Fe-rich smectites such as nontronite. The $819 \mathrm{~cm}^{-1}$ band may originate from $\mathrm{OH}-$ bending vibrations at the $\mathrm{Fe}(\mathrm{III})-\mathrm{OH}$ site, indicating $\mathrm{Fe}$ in the octahedral sheet of smectite (Bangira et al., 2011). Hence, the presence of this band in the clay fractions of the soils and its absence from the parent-rock material seems to confirm the XRD data of decreasing smectite with soil depth (cf. Table 3).

\section{DISCUSSION}

Based on the soil morphology and basic soil properties (Table 1), the pedons studied were all classified as Lithic Udorthents according to US Soil Taxonomy (Soil Survey Staff, 2010), which formed during the Holocene and which are incipient in soil development. Nevertheless, soil-chemical parameters and clay mineralogy clearly showed progressive weathering towards the soil surface. For example, the total $\mathrm{Mg} / \mathrm{Ca}$ ratio decreased substantially, e.g. from 32 in the $\mathrm{C}$ horizon to 3.2 in the Ap horizon of Pedon 1 (Table 2) based on the total analysis of elements. Such changes in the $\mathrm{Mg} / \mathrm{Ca}$ ratio have been attributed to the degree of soil weathering (McGahan et al., 2009).

Based on the micromorphology, XRD, and FTIR analyses, abundant serpentine and chlorite were found in all pedons. In addition, pyroxene, amphibole, talc, and chromite were present in the parent-rock materials. These minerals are characteristic of serpentinites (Alexander et al., 2007), and their weathering releases $\mathrm{Cr}$ and $\mathrm{Ni}$ and may lead to the formation of various clay minerals (Lee et al., 2003; Hseu et al., 2007). These clay phases also generally contain some adsorbed $\mathrm{Cr}$ and $\mathrm{Ni}$ (Caillaud et al. 2006; Hseu et al., 2007; Garnier et al., 2009). In the present study, the dominant pedogenic minerals were smectite, vermiculite, and interstratified chlorite-vermiculite; they were present in all Ap and AC horizons but absent from the $\mathrm{C}$ horizons; in Pedon 3 , in particular, they showed a clear increase towards the soil surface (Table 3). 
Table 3. Semi-quantitative clay-mineral composition in the study pedons ${ }^{1}$.

\begin{tabular}{|c|c|c|c|c|c|c|c|c|}
\hline Horizon & Chl & Sme & $\mathrm{C}-\mathrm{V}$ & Ver & Ser & Mica & Pla & Chr \\
\hline \multicolumn{9}{|l|}{ Pedon 1} \\
\hline Ap & $++^{2}$ & + & + & + & + & + & + & + \\
\hline $\mathrm{AC}$ & +++ & + & + & + & ++ & - & + & + \\
\hline $\mathrm{C}$ & +++ & - & - & - & ++ & - & + & ++ \\
\hline \multicolumn{9}{|l|}{ Pedon 2} \\
\hline Ap & ++ & + & + & + & + & + & - & + \\
\hline $\mathrm{AC}$ & +++ & + & + & + & ++ & - & + & + \\
\hline $\mathrm{C}$ & +++ & - & - & - & ++ & - & + & + \\
\hline \multicolumn{9}{|l|}{ Pedon 3} \\
\hline Ap & ++ & + & ++ & ++ & + & + & - & + \\
\hline $\mathrm{AC} 1$ & ++ & + & + & + & + & - & - & + \\
\hline $\mathrm{AC} 2$ & +++ & + & + & + & ++ & - & + & + \\
\hline $\mathrm{C}$ & +++ & - & - & - & ++ & - & + & ++ \\
\hline
\end{tabular}

${ }^{1}$ Chl: chlorite; Sme: smectite; C-V: chlorite-vermiculite mixed layers; Ver: vermiculite; Ser: serpentine; Pla: plagioclase; Chr: chromite.

${ }^{2}+++$ : 25-50\%; ++: 10-25\%; +: $<10 \%$; -: undetectable.

The parent-rock materials and soils also contained mica, plagioclase, and quartz (Figures 3 and 4, Table 3). In previous studies of ultramafic-derived soils in temperate regions, trace amounts of mica, quartz, and feldspars were reported and attributed to aeolian deposition or colluvial materials from other sources (Alexander et al., 2007). These minerals probably originated from mixing of the serpentinite material with other material during colluvial and alluvial transport. This is substantiated by the co-existence of areas with distinct mineralogy identified by X-ray on thin sections (Figure 4). Long-distance aeolian transport was shown by Hseu et al. (2007) to have supplied little quartz in the HLV area of eastern Taiwan.
A principal distinction between paddy soils and upland soils is the variations in oxidation and reduction status, which may strongly affect clay mineralogy (KögelKnabner et al., 2010). Favre et al. (2002) investigated the changes in structural mineral iron in a soil, containing smectite and kaolinite as the dominant clay minerals, that was cropped with paddy rice twice a year for $11 \mathrm{y}$. They found that structural smectite $\mathrm{Fe}^{2+}$ increased upon reduction but, nevertheless, the $\mathrm{Fe}$ contents of the Ap horizon were less than those in soils of uncropped neighboring land, suggesting that inundation induced weathering and eluviation of the released elements.

The parent materials of the studied soils, containing pyroxene, amphibole, talc, serpentine, and chlorite, are

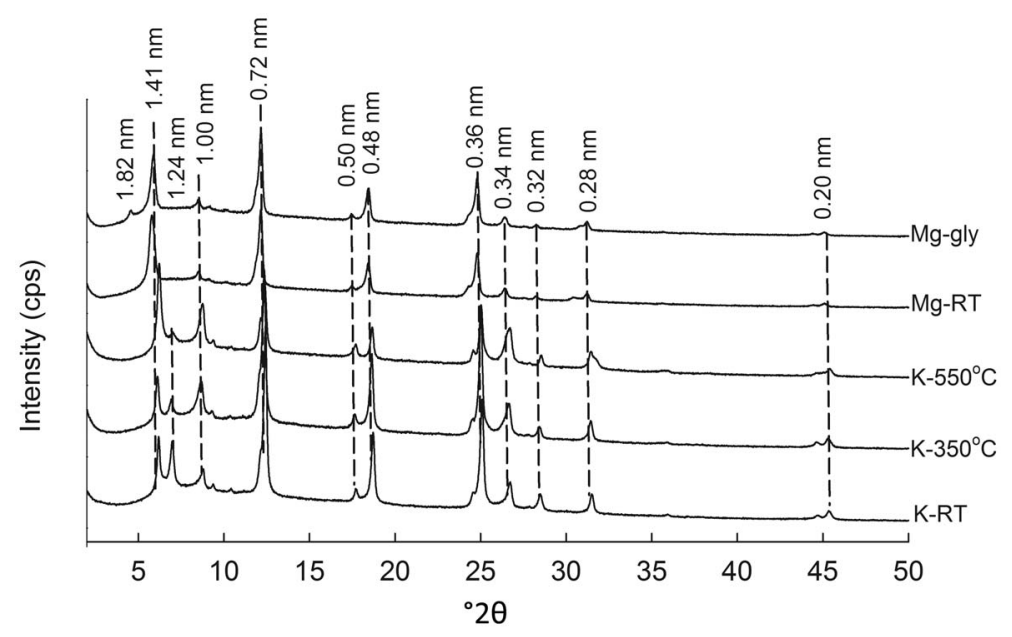

Figure 5. XRD patterns of the clay fraction from the Ap horizon of Pedon 3, with K-saturated treatments at room temperature (K-RT), $350^{\circ} \mathrm{C}$, and $550^{\circ} \mathrm{C}$, and with $\mathrm{Mg}$-saturated treatments at room temperature (Mg-RT) and after glycerol solvation $(\mathrm{Mg}-\mathrm{Gly})$. 


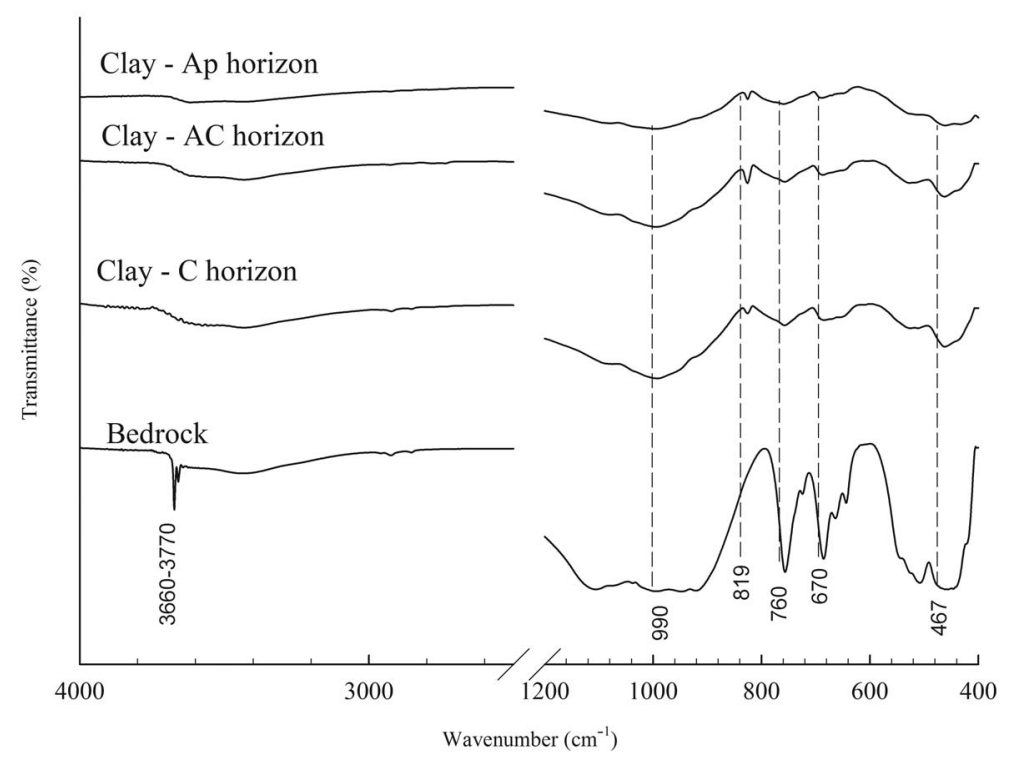

Figure 6. FTIR spectra of parent-rock material and clay fractions from the three horizons of Pedon 2.

relatively unstable in the field (Hseu et al., 2007; McGahan et al., 2008; Lessovaia et al., 2012), and weathered readily in these paddy soils exposed to tropical climate, with an initial loss of cations, notably $\mathrm{Mg}$ and $\mathrm{Fe}$ (Table 2), from the mineral structures (Berner and Schott, 1982). Release of these cations probably facilitated the formation of smectite (nontronite), vermiculite, and interstratified chlorite-vermiculite under conditions of limited percolation in the soils (Bonifacio et al., 1997; Lee et al., 2003).

The flooding required for paddy rice production might also make the studied soils prone to ferrolysis (Kyuma, 2004). This process could explain the relative increase in short-range-ordered $\mathrm{Fe}$ oxides in the $\mathrm{Ap}$ horizons compared to the $\mathrm{AC}$ or $\mathrm{C}$ horizons ( $\mathrm{cf}$. $\mathrm{Fe}_{\mathrm{o}} / \mathrm{Fe}_{\mathrm{d}}$; Table 1), while there was no difference in $\mathrm{Fe}_{\mathrm{o}} / \mathrm{Fe}_{\mathrm{d}}$ between surface soil and subsoil in upland soils of a serpentinitic toposequence in eastern Taiwan (Hseu, 2006). The Fe released could also be involved in the observed partial hydroxyl interlaying of smectite and incomplete interlayer $\mathrm{OH}$ sheets of chlorite (Dousova et al., 2014). Also, the FTIR spectra suggest the formation of Fe-rich smectite (Figure 6).

Serpentine and chlorite were suggested by Lee et al. (2003) to have transformed into low-charge and highcharge smectites, respectively, in poorly drained soils from serpentinites in California, but only low-charge smectite was found in the present study. The removal of $\mathrm{Fe}$ and $\mathrm{Mg}$ from the interlayer $\mathrm{OH}$ sheets is an important step in the weathering of chlorite to vermiculite. Vermiculite further transforms to high-charge smectite through a loss of charge in the octahedral sheet as $\mathrm{Fe}^{2+}$ is oxidized (Bonafacio et al., 1997). The flooding, however, might have retarded the oxidation of $\mathrm{Fe}^{2+}$ to form high-charge smectite from vermiculite in this study.
Based on the aforementioned findings, the following pathways are proposed for the mineral transformation in the paddy soils studied:

(1) Pyroxene, amphibole, and talc $\rightarrow$

(2) Serpentine $\rightarrow$ low-charge smectite

(3) Chlorite $\rightarrow$ interstratified chlorite-vermiculite $\rightarrow$ vermiculite

The susceptibility of serpentine minerals to weathering has been linked to enhanced availability of $\mathrm{Cr}$ and $\mathrm{Ni}$ in serpentine soils (Caillaud et al., 2006; Morrison et al., 2009; Cheng et al., 2011). In the present study, all pedons showed a marked enrichment of labile $\mathrm{Cr}$ and $\mathrm{Ni}$ in the surface soils relative to the subsoils (Table 1). These depth trends probably reflect the release of $\mathrm{Cr}$ and $\mathrm{Ni}$ upon weathering of the ultramafic parent material followed by their sorption (in labile form) on the surfaces of transformed clay minerals. Other, external sources of $\mathrm{Cr}$ and $\mathrm{Ni}$ probably play a minor role. No industrial activity exists in the HLV area, and strict regulation standards imposed by the Taiwanese government limit the input of heavy metals from irrigation water and compost. In Taiwan, the limits of $\mathrm{Cr}$ and $\mathrm{Ni}$ for irrigation water are 0.1 and $0.2 \mathrm{mg} \mathrm{L}^{-1}$, respectively, and the control standards for compost are 50 and $25 \mathrm{mg}$ $\mathrm{kg}^{-1}$, respectively. The concentrations of $\mathrm{Cr}$ and $\mathrm{Ni}$ in the irrigation water in the vicinity of the studied paddy field were below the detection limit $\left(<0.005 \mathrm{mg} \mathrm{L}^{-1}\right)$ (Chang, 2014). Little manure compost $\left(<10\right.$ ton ha ${ }^{-1}$ $\mathrm{y}^{-1}$ ) has been applied to the studied soils, contributing only trace amounts of $\mathrm{Cr}$ and Ni. Therefore, the main source of $\mathrm{Cr}$ and $\mathrm{Ni}$ in the studied soils appears to be the parent material rather than dust, fertilizer, or irrigation. This is in line with a number of studies that have shown high concentrations of $\mathrm{Cr}$ and $\mathrm{Ni}$ originating from parent 
materials in serpentinitic soils without human activities (Bonifacio et al., 1997; Hseu, 2006; Hseu et al., 2007; Garnier et al., 2009; Cheng et al., 2011).

Compared to serpentine and chlorite, chromite, which is a primary Cr-bearing mineral in serpentinitic soils, is much more resistant to weathering (Hseu and Iizuka, 2013). This probably explains why the amount of extractable $\mathrm{Cr}$ was much smaller than the extractable $\mathrm{Ni}$ in this study. While the observed release of $\mathrm{Cr}$ and $\mathrm{Ni}$ may pose a threat to the environment and to human health, the present authors also found fibrous minerals including amphibole and chrysotile asbestos in the studied paddy soils (Figure 2), which are known human carcinogens (International Agency for Research on Cancer, 2012) and may cause disease if inhaled by humans (Camargo et al., 2011).

\section{CONCLUSIONS}

The studied paddy soils are incipient in their development. Nevertheless, clear indications of chemical weathering and mineral transformations toward the soil surface were found. $\mathrm{Fe}$ and $\mathrm{Mg}$ were released from the ultramafic parent material, and the minerals of the parent material were transformed to secondary minerals, notably low-charge smectite, vermiculite, and mixedlayer chlorite-vermiculite. These findings support the low stability of serpentinites reported in previous studies. In the present study, the observed weathering of the serpentinitic parent material resulted in a marked release of labile $\mathrm{Cr}$ and $\mathrm{Ni}$ toward the soil surface. This shows that even in slightly developed serpentinitic soils (Entisols), weathering under paddy-rice production (i.e. alternating redox conditions) and tropical climate can lead to a significant release of heavy metals from the parent material. These could pose a threat to the environment and to human health.

\section{ACKNOWLEDGMENTS}

The authors thank the Ministry of Science and Technology of the Republic of China, Taiwan for supporting this research financially under Contracts No. NSC 99-2313-B-020-010-MY3 and NSC 102-2313-B020009-MY3.

\section{REFERENCES}

Alexander, E.B. (2014) Arid to humid serpentine soils, mineralogy, and vegetation across the Klamath Mountains, USA. Catena, 116, 114-122.

Alexander, E.B., Coleman, R.G., Keeler-Wolf, T., and Harrison, S. (2007) Serpentine soil distributions and environmental influences. Pp. 55-78 in: Serpentine Geoecology of Western North America (E.B. Alexander, R.G. Coleman, T. Keeler-Wolf, and S. Harrison, editors). Oxford University Press, New York.

Baker, D.E. and Amacher, M.C. (1982) Nickel, copper, zinc, and cadmium, Pp. 323-336 in: Methods of Soil Analysis, Part 2, Chemical and Microbiological Properties, $2^{\text {nd }}$ edition (A.L. Page, R.H. Miller, and D.R. Keeney, editors).
Agronomy Monograph No. 9, Agronomy Society of America and Soil Science Society of America, Madison, Wisconsin, USA.

Bangira, C., Deng, Y., Loeppert, R.H., Hallmark, C.T., and Stucki, J.W. (2011) Soil mineral composition in constrasting climatic regions of the Great dyke, Zimbabwe. Soil Science Society of America Journal, 75, 2367-2378.

Becquer, T., Quantin, C., and Boudot, J.B (2010) Toxic levels of metals in Ferralsols under natural vegetation and crops in New Caledonia. European Journal of Soil Science, $\mathbf{6 1}_{2}$ 994-1004.

Berner, R.A. and Schott, J. (1982) Mechanism of pyroxene and amphibole weathering: II. Observations of soil grains. American Journal of Science, 282, 1214-1231.

Bonifacio, E. and Barberis, E. (1999) Phosphorus dynamics during pedogenesis on serpentinite. Soil Science, 164, 960-968.

Bonifacio, E., Zanini, E., Boero, V., and Franchini-Angela, M. (1997) Pedogenesis in a soil catena on serpentinite in northwestern Italy. Geoderma, 75, 33-51.

Brooks, R.R. (1987) Serpentine and its Vegetation: a Multidisciplinary Approach. Croom Helm, London.

Caillaud, J., Proust, D., and Righi, D. (2006) Weathering sequences of rock-forming minerals in a serpentinite: influence of microsystems on clay mineralogy. Clays and Clay Minerals, 54, 87-100.

Camargo, M., Stayner, L., Straif, K., Reina, M., Al-Alem, U., Demers, P., and Landrigan, P. (2011) Occupational exposure to asbestos and ovarian cancer. Environmental Health Perspectives, 119, 1211-1217.

Chang, Y.C. (2014) The investigation of extractable $\mathrm{Cr}$ and $\mathrm{Ni}$ concentrations and soil properties for serpentinitic soils. Master Thesis, Department of Environmental Science and Engineering, National Pingtung University of Science and Technology, Pingtung, Taiwan, 62 pp. (in Chinese with English abstract).

Chen, Y. (2013) Heavy metals uptake of paddy rice on serpentine soils with different fertilizer treatments. Master Thesis, Department of Environmental Science and Engineering, National Pingtung University of Science and Technology, Pingtung, Taiwan, 70 pp. (in Chinese with English abstract).

Cheng, C.H., Jien, S.H., Tsai, H., Chang, Y.H., Chen, Y.C., and Hseu, Z.Y. (2009) Geochemical element differentiation in serpentine soils from the ophiolite complexes, eastern Taiwan. Soil Science, 174, 283-291.

Cheng, C.H., Jien, S.H., Iizuka, Y., Tsai, H., Chang, Y.H., and Hseu, Z.Y. (2011) Pedogenic chromium and nickel partitioning in serpentine soils along a toposequence. Soil Science Society of America Journal, 75, 659-668.

Dixon, J.B. (1989) Kaolin and serpentine group minerals. Pp. 467-526 in: Minerals in Soil Environments, $2^{\text {nd }}$ edition (J.B. Dixon and S.B. Weed, editors). Soil Science Society of America Book Series No. 1, Soil Science Society of America, Madison, Wisconsin, USA.

Dousova, B., Fuitova, L., Kolousek, D., Lhotka, M., Grygar, T.M., and Spurna, P. (2014) Stability of iron in clays under different leaching conditions. Clays and Clay Minerals, 62, $145-152$.

Economou-Eliopoulos, M., Megremi, I., and Vasilatos, C. (2011) Factors controlling the heterogeneous distribution of $\mathrm{Cr}(\mathrm{VI})$ in soil, plants and groundwater: Evidence from the Assopos basin, Greece. Chemie der Erde, 71, 39-52.

Fantoni, D., Brozzo, G., Canepa, M., Cipolli, F., Marini, L., Ottonello, G., and Zuccolini, M.V. (2002) Natural hexavalent chromium in groundwaters interacting with ophiolitic rocks. Environmental Geology, 42, 871-882.

Farmer, V.C. (1974) The layer silicates. Pp. 331-364 in: The Infrared Spectra of Minerals (V.C. Famer editor). 
Monograph No. 4, Mineralogical Society, London.

Favre, F., Tessier, D., Abdelmoula, M., Génin, J.M., Gates, W.P., and Boivin, P. (2002) Iron reduction and changes in cation exchange capacity in intermittently waterlogged soil. European Journal of Soil Science, 53, 175-183.

Garnier, J., Quantin, C., Guimarães, E., Garg, V.K., Martins, E.S., and Becquer, T. (2009) Understanding the genesis of ultramafic soils and catena dynamics. Geoderma, 151, 204-214.

Gaudin, A., Decarreau, A., Noack, Y., and Graby, O. (2005) Clay mineralogy of the nickel laterite ore developed from serpentinised peridotites at Murrin Murrin, Western Australia. Australian Journal of Earth Science, 52, $231-241$.

Gee, G.W. and Bauder, J.W. (1986) Particle-size analysis. Pp. 383-411 in: Methods of Soil Analysis, Part 1, $2^{\text {nd }}$ edition (A. Klute, editor). Agronomy Monograph No. 9. American Society of Agronomy and Soil Science Society of America, Madison, Wisconsin, USA.

Graham, R.C., Diallo, M.M., and Lund, L.J. (1990) Soils and mineral weathering on phyllite colluvium and serpentinite in northwestern California. Soil Science Society of America Journal, 54, 1682-1690.

Hseu, Z.Y. (2006) Concentration and distribution of chromium and nickel fractions along a serpentinitic toposequence. Soil Science, 171, 341-353.

Hseu, Z.Y. and Chen, Z.S. (1996) Saturation, reduction, and redox morphology of seasonally flooded Alfisols in Taiwan. Soil Science Society of America Journal, 60, 941-949.

Hseu, Z.Y. and Chen, Z.S. (2001) Quantifying soil hydromorphology of a rice-growing Ultisol toposequence in Taiwan. Soil Science Society of America Journal, 65, $270-278$.

Hseu, Z.Y. and Iizuka, Y. (2013) Pedogeochemical characteristics of chromite in a paddy soil derived from serpentinites. Geoderma, 202-203, 126-133.

Hseu, Z.Y., Tsai, H., Hsi, H.C., and Chen, Y.C. (2007) Weathering sequences of clay minerals in soils along a serpentinitic toposequence. Clays and Clay Minerals, 55, $389-401$.

International Agency for Research on Cancer (2012) Asbestos. Pp. 219-294 in: A Review of Human Carcinogens. IARC Monograph on the Evaluation of Carcinogenic Risks to Humans 100C. WHO Press, Lyon, France.

Istok, J.D. and Harward, M.E. (1982) Influence of soil moisture on smectite formation in soils derived from serpentinite. Soil Science Society of America Journal, 46, $1106-1108$.

Jien, S.H., Tsai, C.C., Hseu, Z.Y., and Chen, Z.S. (2011) Baseline concentrations of toxic elements in metropolitan park soils of Taiwan. Terrestrial and Aquatic Environmental Toxicology, 5, 1-7.

Johns, W.D., Grim, R.E., and Bradley, W.F. (1954) Quantitative estimations of clay minerals by diffraction methods. Journal of Sedimentary Petrology, 24, 242-251.

Kahle, M., Kleber, M., and Jahn, R. (2002) Review of XRDbased quantitative analyses of clay minerals in soils: the suitability of mineral intensity factors. Geoderma, 109, $191-205$.

Kögel-Knabner, I., Amelung, W., Cao, Z., Fiedler, S., Frenzel, P., Jahn, R., Kalbitz, K., Kölbl, A., and Schloter, M. (2010) Biogeochemistry of paddy soils. Geoderma, 157, 1-14.

Kyuma, K. (2004) Paddy Soil Science. Kyoto University Press, Kyoto, Japan, 280 pp.

Lee, B.D., Sears, S.K., Graham, R.C., Amrhein, C., and Vali, H. (2003) Secondary mineral genesis from chlorite and serpentine in an ultramafic soil toposequence. Soil Science Society of America Journal, 67, 1309-1317.

Lessovaia, S.N. and Polekhovsky, Y.S. (2009) Mineralogical composition of shallow soils on basic and ultrabasic rocks of eastern Fennoscandia and of the Ural Mountains, Russia. Clays and Clay Minerals, 57, 476-485.

Lessovaia, S., Dultz, S., Polekhovsky, Y., Krupskaya, V., Vigasina, M., and Melchakova, L. (2012) Rock control of pedogenic clay mineral formation in a shallow soil from serpentinous dunite in the Polar Urals, Russia. Applied Clay Science, 64, 4-11.

McGahan, D.G., Southard, R.J., and Claassen, V.P. (2008) Tectonic inclusions in serpentinite landscapes contribute plant nutrient calcium. Soil Science Society of America Journal, 72, 838-847.

McGahan, D.G., Southard, R.J., and Claassen, V.P. (2009) Plant-available calcium varies widely in soils on serpentinite landscapes. Soil Science Society of America Journal, 73, 2087-2095.

McKeague, J.A. and Day, J.H. (1966) Dithionite and oxalate extractable $\mathrm{Fe}$ and $\mathrm{Al}$ as aids in differentiating various classes of soils. Canadian Journal of Soil Science, 46, $13-22$

McLean, E.O. (1982) Soil $\mathrm{pH}$ and lime requirement. Pp. 199-224 in: Methods of Soil analysis, Part 2, Chemical and Microbiological Properties, $2^{\text {nd }}$ edition (A.L. Page, R.H. Miller, and D.R. Keeney, editors). Agronomy Monograph No. 9. American Society of Agronomy and Soil Science Society of America, Madison, Wisconsin, USA.

Mehra, O.P. and Jackson, M.J. (1960) Iron oxides removed from soils and clays by a dithionite-citrate system buffered with sodium bicarbonate. Clays and Clay Minerals, 7, $317-327$.

Morrison, J.M., Goldhaber, M.B., Lee, L., Holloway, J.M., Wanty, R.B., Wolf, R.E., and Ranville, J.F. (2009) A regional-scale study of chromium and nickel in soils of northern California, USA. Applied Geochemistry, 24, $1500-1511$.

Nelson, D.W. and Sommers, L.E. (1982) Total carbon, OC, and organic matter. Pp. 539-557 in: Methods of Soil Analysis, Part 2, Chemical and Microbiological Properties, $2^{\text {nd }}$ edition (A.L. Page, R.H. Miller, and D.R. Keeney, editors). Agronomy Monograph No. 9. American Society of Agronomy and Soil Science Society of America, Madison, Wisconsin, USA.

Nkoumbou, C., Villieras, F., Barres, O., Bihannic, I., Pelletier, M., Razafitianamaharavo, A., Metang, V., Yonta Ngoune, C., Njopwouo, D., and Yvon, J. (2008) Physicochemical properties of talc ore from Pout-Kelle and Memel deposits (central Cameroon). Clay Minerals, 43, 317-337.

Norrish, K. and Hutton, J.T. (1969) An accurate X-ray spectrographic method for the analysis of a wide range of geological samples. Geochimica et Cosmochimica Acta, 33, $431-453$.

O'Hanley, D.S. (1996) Serpentinites: Records of Tectonic and Petrological History. Oxford University Press, New York.

Oze, C., Bird, D.K., and Fendorf, S. (2007) Genesis of hexavalent chromium from natural sources in soil and groundwater. Proceedings of the National Academy of Sciences, 17, 6544-6549.

Oze, C., Skinner, C., Schroth, A., and Coleman, R.G. (2008) Growing up green on serpentine soils: Biogeochemistry of serpentine vegetation in the Central Coast Range of California. Applied Geochemistry, 23, 3391-3403.

Rabenhorst, M.C., Foss, J.E., and Fanning, D.S. (1982) Genesis of Maryland soils formed from serpentinite. Soil Science Society of America Journal, 46, 607-616.

Rhoades, J.D. (1982) Cation exchangeable capacity. Pp. 149-157 in: Methods of Soil Analysis, Part 2, Chemical and Microbiological Properties, $2^{\text {nd }}$ edition (A.L. Page, R.H. Miller, and D.R. Keeney, editors). Agronomy Monograph No. 9. American Society of Agronomy and 
Soil Science Society of America, Madison, Wisconsin, USA.

Soil Survey Staff (1993) Examination and description of soils in the field. Pp. 59-196 in: Soil Survey Manual. Issued October, 1993. Handbook No. 18, USDA-Soil Conservation Service, Washington, D.C.

Soil Survey Staff (2010) Keys to Soil Taxonomy, $12^{\text {th }}$ edition. USDA, Natural Resources Conversation Services, Washington, D.C., 332 pp.

Suquet, H. (1989) Effects of dry grinding and leaching on the crystal structure of chrysotile. Clays and Clay Minerals, 3 , 439-445.

Wanze, M., Jagupilla, S.C., Moon, D.H., Christodoulatos, C., and Koutsospyros, A. (2008) Leaching mechanisms of $\mathrm{Cr}(\mathrm{VI})$ from chromite ore processing residue. Journal of Environmental Quality, 37, 2125-2134.
Whittaker, R.H. (1954) The ecology of serpentine soils. IV. The vegetation response to serpentine soils. Ecology, 35, $275-288$.

Wicks, F.J. and O'Hanley, D.S. (1988) Serpentine minerals: structures and petrology. Pp. 91-167 in: Hydrous Phyllosilicates (Exclusive of Micas) (S.W. Bailey, editor). Reviews in Mineralogy and Geochemistry, 19, Mineralogical Society of America, Washington, D.C.

Yongue-Fouateu, R., Yemefack, M., Wouatong, A.S.L., Ndjigui, P.D., and Bilong, P. (2009) Contrasted mineralogical composition of the laterite cover on serpentinites of Nkamouna-Kongo, southeast Cameroon. Clay Minerals, 44, $221-237$.

(Received 5 May 2014; revised 8 April 2015; Ms. 873; AE: A. Thompson) 